\title{
Novo Mundo historiográfico: As Américas na pauta de Sérgio Buarque de Holanda, Ruggiero Romano e Max Savelle
}

\begin{abstract}
Bruno Silva ${ }^{1}$
André Furtado. ${ }^{2}$

Resumo: este artigo analisa o encontro entre os historiadores Sérgio Buarque de Holanda, Ruggiero Romano e Max Savelle, em 1963, reunidos na capital chilena, Santiago, a convite do colega de ofício, Eugenio Pereira Salas. A ideia consistia em ministrar um curso de perspectiva continental junto ao Centro de Investigaciones de Historia Americana (CIHA), pois cada um deveria falar de uma parcela do antigo Novo Mundo, com destaque para as porções dos domínios luso, castelhano e inglês. Tais professores eram vinculados à Universidade de São Paulo (USP), à École Pratique des Hautes Études (EPHE), à University of Washington (UW) e à Universidad de Chile, respectivamente. Aqui dar-se-á ênfase às suas aulas inaugurais, com especial interesse sobre o conteúdo e o peso do discurso historiográfico veiculado, para além de uma narrativa europeia a respeito dos passados que abordaram.

Palavras-chave: Centro de Investigaciones de Historia Americana (CIHA); aulas inaugurais; discurso historiográfico.

\section{The historiography of New World: \\ The American continent on the agenda of Sérgio Buarque de Holanda, Ruggiero Romano and Max Savelle}

\begin{abstract}
Sérgio Buarque de Holanda, Ruggiero Romano and Max Savelle, in 1963 in the capital of Chile, Santiago, at Eugenio Pereira Salas's invitation, a colleague of the three. The idea was to teach a course of continental perspective to the Centro de Investigaciones de Historia Americana (CIHA), since each one

\footnotetext{
${ }^{1}$ Doutor em História pela Universidade Federal Fluminense (UFF, Niterói - Brasil), com bolsa da Coordenação de Aperfeiçoamento de Pessoal de Nível Superior (CAPES) e estágio na University of Texas (UT, Austin - EUA) por meio do Programa de Doutorado Sanduíche no Exterior (PDSE). Atualmente é Professor Adjunto A de História da América da Universidade Federal do Sul e Sudeste do Pará (UNIFESSPA) e desenvolve a seguinte pesquisa: Os relatos de viagens no século XVIII e o projeto de reconstrução da ideia de América e do homem americano: do nascimento de raça e racismo modernos (com aluno bolsista de Iniciação Científica, financiado pelo Conselho Nacional de Desenvolvimento Científico e Tecnológico - CNPq). Endereço para correspondência: Rua Maranhão (esquina com Xingu), s./n, Universidade Federal do Sul e Sudeste do Pará (UNIFESSPA), Centro - Xinguara / PA, CEP.: 68555251. Home page: https://sigaa.unifesspa.edu.br/sigaa/public/docente/portal.jsf?siape=2395806. E-mail: slvbruno@unifesspa.edu.br \& slvbruno2004@yahoo.com.br.

${ }^{2}$ Doutor em História pela Universidade Federal Fluminense (UFF, Niterói - Brasil), com bolsa da Coordenação de Aperfeiçoamento de Pessoal de Nível Superior (CAPES) e estágio na École des Hautes Études en Sciences Sociales (EHESS, Paris - França) por meio do Programa de Doutorado Sanduíche no Exterior (PDSE). E-mail: afurtado@id.uff.br \& furtado1989@gmail.com. Atualmente realizada Pós-doutorado, com bolsa da Fundação Carlos Chagas Filho de Amparo à Pesquisa do Estado do Rio de Janeiro (FAPERJ) junto à citada UFF. Endereço para correspondência: Instituto de História (IHT). Campus do Gragoatá, Rua Professor Marcus Waldemar de Freitas Reis, Bloco O, Niterói / Rio de Janeiro (RJ) - Brasil. Telefone: 55 (021) 2629-2919.
}

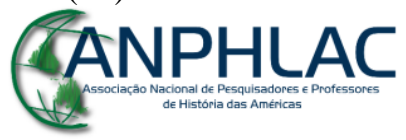

Revista Eletrônica da ANPHLAC, ISSN 1679-1061, № 27, p.347-378 , Ago./Dez., 2019. http://revista.anphlac.org.br 
should speak of a part of the old New World, with emphasis on those of Portuguese, Castilian and English dominion. These professors were linked to the Universidade de São Paulo (USP), the École Pratique des Hautes Études (EPHE), the University of Washington (UW) and the Universidad de Chile, respectively. Here, emphasis will be placed on his inaugural lectures, with special interest in the content and weight of the historiographical discourse conveyed, as well as a European narrative about the pasts they approached.

Keywords: Centro de Investigaciones de Historia Americana (CIHA); inaugural classes; historiographic discourse.

Artigo recebido em: 18/06/2018

Artigo aprovado para publicação em: 08/04/019

\begin{abstract}
Historiadores nunca foram bons profetas, mas às vezes, recordando que o presente é feito de passados em camadas ou emaranhados, têm sido capazes de contribuir para um diagnóstico mais lúcido das novidades que seduzem ou assustam seus contemporâneos (Roger Chartier)
\end{abstract}

Corria o ano de 1962 quando, em dezembro, Eugenio Pereira Salas, então diretor do Centro de Investigaciones de História Americana (CIHA), escreveu a seus pares de ofício Sérgio Buarque de Holanda (brasileiro), Ruggiero Romano (italiano) e Max Hicks Savelle (estadunidense). Nas cartas que seguiram viagem estavam os pedidos para que eles ministrassem cursos em seu país, junto ao recém-criado instituto de pesquisas do departamento de Filosofia e Letras da Universidad de Chile, em Santiago. Ao anunciar o objetivo do CIHA ou seja: "estimular en un nivel intelectual elevado la rebusca y la enseñanza de la História de América" -, Pereira Salas os convidava para integrarem o ano letivo de 1963 que, "gracias a la ayuda generosa de la Fundación Rockefeller", teria um curso inédito dividido em três unidades sobre o continente, principiando-se pelo estudo do Brasil, pois, neste caso, planejavam criar uma cátedra. ${ }^{3}$

A trajetória de Eugenio Pereira Salas (1904-1979) é marcada pelo ingresso como estudante, em 1924, no Instituto Pedagógico na Universidad de Chile, tendo obtido quatro anos

\footnotetext{
${ }^{3}$ As citações do parágrafo foram extraídas da Série: Correspondência. Subsérie: Passiva. 470 - Carta em espanhol de Eugenio Pereira Salas a Sérgio Buarque de Holanda, convidando-o para que ministrasse um curso sobre História do Brasil no Centro de Investigaciones de História Americana (CIHA). Santiago do Chile, 14 dez. 1962. as. ileg. 1p. Cp 248 P9. Fundo "Sérgio Buarque de Holanda" (SBH). Sistema de Arquivos da Universidade Estadual de Campinas (Siarq-UNICAMP). Optamos por deixar todas as referências de fontes primárias em notas de rodapé.
}

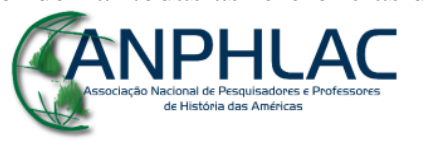

Revista Eletrônica da ANPHLAC, ISSN 1679-1061, N.27, p. 347-378, Ago./Dez., 2019. http://revista.anphlac.org.br 
depois o título de professor em História, Geografia e Educação Cívica. Nesse entremeio, porém, havia passado uma temporada na Europa, momento em que pôde estabelecer alguns laços com instituições de ensino superior na Inglaterra e sobretudo na França, onde foi discente na Sorbonne. Ainda em Paris entrou em contato com reconhecidos docentes, tais como Charles Seignobos (1854-1942), Henri Hauser (1866-1946) e Pierre Renouvin (1893-1974). No ano de 1930 acompanhou seminários em Berlim, Alemanha, dirigindo-se em seguida a várias regiões da Espanha dando início às suas primeiras pesquisas de arquivo. De 1933 a 1934, por meio de uma bolsa de estudos da John Simon Guggenheim Memorial Foundation e sob orientação de Herbert Eugene Bolton (1870-1953), iniciou estudos americanistas na University of California, Berkeley, nos Estados Unidos. Grande parte de seus interesses investigativos se voltaram à música, ao teatro e às belas-artes do período colonial ao século XIX (MERINO, 1979).

Além do CIHA, Pereira Salas ajudou a fundar o Instituto de Investigaciones Musicales (IIM), atuou no Instituto Chileno-Norteamericano de Cultura (ICNC) e na Academia Chilena de História (AChHi), a qual passou a presidir a partir de 1962 (Cf. EL historiador da la cultura chilena..., 2019), reunindo assim grande capital simbólico.

Até o momento em que se reuniu com os colegas, em 1963, suas publicações de maior destaque eram: Los orígenes del arte musical en Chile (1941); Apuntes para la história de la cocina chilena (1943); Juegos y alegrías coloniales en Chile (1947); Guía bibliográfica para el estudio del folklore chileno (1952); América del Sur: Perú, Bolivia, Paraguay, Argentina, Chile: periodo nacional (1956); \& História de la música en Chile: 1850-1900 (1957).

Por corresponder a uma pesquisa em curso - e na falta, por ora, de acesso a documentos relativos a Romano e Savelle -, assumimos o risco de encarar o teor da missiva de Pereira Salas a Buarque de Holanda como extensivo a todos os envolvidos. Na continuidade do estudo investigaremos os papéis esparsos relativos a Romano que localizamos entre os documentos depositados nos Archives de la Fundation Maison de Scienses de l'Homme (FMSH), Paris França; e, no caso de Savelle, materiais dessa natureza podem ser encontrados nos Archives West, da University of Washington (UW), Seattle - Estados Unidos da América (EUA), no qual já mapeamos fontes relativas aos seus contatos intelectuais e institucionais com o Chile.

\section{CANPHLAC}

Revista Eletrônica da ANPHLAC, ISSN 1679-1061, №.27 , p. 347-378, Ago./Dez., 2019. http://revista.anphlac.org.br 
Quanto à atenção voltada ao Brasil, face à possibilidade de criação de uma cátedra específica na capital Santiago, pode-se dizer que talvez o destaque lançado em torno do país vizinho se relacionasse ao fato de nele se processar, à época, um lento estabelecimento da História como disciplina acadêmica (RODRIGUES, 2012). Tamanha transformação, no entanto, seguia os passos daquilo que vinha ocorrendo nessa área em outras partes da América Latina, nas quais o campo em destaque passava por grandes mudanças. Faz-se necessário registrar, aliás, que compreendemos a ideia de campo no sentido do universo no qual estão inseridos os agentes e as instituições para (re)produzirem e/ou difundirem a arte, a literatura etc. Trata-se de um espaço que ao obedecer regras sociais mais ou menos específicas, constitui-se de forma relativamente autônoma, pois detém leis próprias (BOURDIEU, 2004).

Isto posto - e aqui vale uma digressão -, torna-se imperioso deixar evidente que apesar do papel de vanguarda que os territórios outrora de domínio espanhol assumiram nas terras colonizadas ao lançarem as bases das universidades ainda no quinhentos, uma modernização sem precedentes começava a atingi-las. Herdeiros das atitudes da Coroa hispânica - e diferentemente do que se passaria na parte lusitana -, as Índias de Castela contaram com a criação de 32 dos chamados colégios maiores, sendo 6 no século XVI, 12 no XVII, 11 no XVIII e três no XIX. A maioria recebeu cédulas reais e bulas papais, autorizando-os, mas desse total 11 fecharam as portas até o fim do setecentos (ARRANGO, 1995, p. 95-97 e 105).

Essa expansão dos espaços precursores das universidades na América espanhola foi mediada pelas ordens religiosas (jesuítas, dominicanos, franciscanos etc.), de modo que suas atividades ajudaram a Igreja Católica a consolidar seu poder e monopólio sobre a educação das elites nos territórios hispânicos do Novo Mundo. Porém, no século XVIII, após o banimento da Companhia de Jesus das jurisdições ibéricas, tal responsabilidade recaiu sobre o episcopado (BARNADAS, 1990, p. 198).

No Brasil, a implantação do ensino superior nesse formato foi infinitamente mais tardia. A Universidade de São Paulo (USP), por exemplo, só foi criada em 1934 e já existe, no país, uma larga bibliografia a propósito de tal debate (MICELI, 1989). Portanto, apesar desse atraso e das instabilidades que rondariam suas existências, as instituições das antigas posses novomundistas portuguesas nasceram apenas no século $\mathrm{XX}$, mas longe do signo eclesiástico. De

\section{CANPHLAC}

Revista Eletrônica da ANPHLAC, ISSN 1679-1061, №.27 , p. 347-378, Ago./Dez., 2019. http://revista.anphlac.org.br 
sorte que, enquanto no Brasil a modernização estaria ela mesma incutida na emergência do sistema universitário, no caso dos países hispanohablantes seus movimentos incluíam a laicização do mundo acadêmico (FURTADO, 2018).

Seja como for, o contrato inicial de Pereira Salas com Buarque de Holanda, Romano e Savelle propunha duas horas semanais de conferências ou leituras dirigidas a um público de conhecimento básico nos assuntos que seriam abordados. $\mathrm{O}$ acordo deixava ainda a encargo dos convidados a escolha dos temas, desde que eles fossem os de suas maiores especialidades e, sobretudo, úteis à feitura de vinculações na área de estudos sobre a América.

Logo, vale sublinhar a centralidade da correspondência como fonte que dá a ler os trâmites dessa negociação intelectual, pois quando feita entre amigos, torna-se um documento privilegiado que viabiliza a análise de laços afetivos, materializados em suas marcas. "A prática epistolar de um indivíduo só existe em função de um outro, para quem se enuncia uma fala e de quem se aguarda uma resposta. É, portanto, uma via de mão dupla, um ir e vir entre uma intenção anunciada, uma espera ansiosa”. Geralmente salvaguardada em acervos privados - o que já denota sua importância para ser legada à posteridade -, uma carta expressa mais que o texto contido nela em si, uma vez que permite visualizar suas condições de produção e circulação. Afinal, a correspondência pessoal de um indivíduo se constitui como um espaço que define e é definido por sua sociabilidade, mediante a qual os sujeitos, "mesmo distantes fisicamente, podem trocar ideias e afetos, construir projetos mútuos ou discutir planos opostos, estabelecer pactos ou polêmicas e organizar ações. Esses documentos permitem, em síntese, esboçar a rede de relações sociais de seus titulares" (VENANCIO, 2001, p. 23-24 \& 32).

Convites aceitos, para lá rumaram os colegas historiadores, em 1963. O primeiro deles, já catedrático da USP, decidiu apresentar um seminário com a temática do Brasil Império. $\mathrm{O}$ segundo, atuante na École Pratique des Hautes Études (EPHE) de Paris, preferiu dar vazão aos seus estudos acerca da História de los precios e Historia colonial hispanoamericana. E o terceiro, da UW de Seattle, optou por falar sobre El espíritu de la Independencia Americana.

A julgar pelo que consta na missiva endereçada a Sérgio Buarque de Holanda, podemos inferir que a todos foi solicitada uma síntese completa dos seus respectivos seminários, que

\section{CANPHLAC}

Revista Eletrônica da ANPHLAC, ISSN 1679-1061, N.27 , p. 347-378, Ago./Dez., 2019. http://revista.anphlac.org.br 
deveria, por sua vez, ser anunciada no primeiro encontro. ${ }^{4}$ Isso porque naquele mesmo ano, essas aulas foram impressas pela instituição por meio do CIHA, sob o título de Tres lecciones inaugurales (HOLANDA; ROMANO; SAVELLE, 1963). Observado esse aspecto, é importante dizer que estamos trabalhando com o exemplar outrora pertencido a Eurípedes Simões de Paula (1910-1977), que talvez o tenha ganhado de Sérgio Buarque, seu colega de departamento na USP, pois este se encontra hoje no acervo do Centro de Apoio à Pesquisa em História de sua Faculdade de Filosofia, Letras e Ciências Humanas (CAPH-FFLCH).

Ao tomar esse livro como documento - que detém o potencial para nos informar sobre o evento supracitado -, o presente artigo visa analisar suas páginas e circunstâncias transformando-as em fontes de informações acerca do referido passado, atentos também às marcas de seus paratextos. Estes últimos remetem aos espaços que circundam a palavra impressa, zona de transição e "transação: lugar privilegiado de uma pragmática e de uma estratégia, de uma ação sobre o público, a serviço, bem ou mal compreendido e acabado, de uma melhor acolhida do texto e de uma leitura mais pertinente" (GENETTE, 2009, p. 10), ao menos do ponto de vista de seus responsáveis imediatos.

Mas nosso especial interesse se voltará ao seu conteúdo e ao peso relativo do discurso historiográfico verbalizado, em cotejo às vicissitudes biobibliográficas dos nomes envolvidos, sempre que possível e pertinente. Por isso, é preciso asseverar que tomamos a historiografia como uma espécie de operação que conjuga o espaço produtivo (econômico, social, político, cultural etc.), o modus operandi e a gênese de textos cuja topografia de interesses é, via de regra, silenciada na narrativa (CERTEAU, 1982).

Outro ponto meritório de ênfase se refere aos diversos níveis temporais que a configuração em apreço compacta. Sobre esse conceito em destaque, por sua vez, compreendemos "o padrão mutável criado pelo conjunto dos jogadores - não só pelos seus intelectos, mas pelo que eles são no seu todo, a totalidade de suas ações nas relações que sustentam uns com os outros" (ELIAS, 2008, p. 142). Isso porque daremos importância às

\footnotetext{
${ }^{4}$ Série: Correspondência. Subsérie: Passiva. 480 - Carta em espanhol de Eugenio Pereira Salas a SBH avisandoo que recebeu sua carta e o espera a fim de organizasse as classes do curso de História do Brasil e preparasse uma aula inaugural onde seria feito um resumo do curso. Santiago do Chile, 16 set. 1963. as. ilegível. 1p. Cp 258 P9. Fundo SBH. Siarq-UNICAMP.
}

\section{CANPHLAC}

Revista Eletrônica da ANPHLAC, ISSN 1679-1061, N.27 , p. 347-378, Ago./Dez., 2019. http://revista.anphlac.org.br 
historicidades dos agentes e instituições contemporâneos ao acontecimento (seus contatos, proximidades de objetos de estudos, trocas letradas, editoriais etc.), além das relativas aos tempos pretéritos por eles anunciados, ou seja: da Era Colonial ao século XIX.

O objetivo do nosso procedimento é fazer com que a análise histórica se imponha, uma vez que esta tem suas especificidades e requisitos próprios, fazendo com que o trabalho do historiador se relacione simultaneamente "com o tempo e o espaço, pois o eixo temporal e as coordenadas espaciais são constitutivos de sua análise". Somando-se isso ao nexo estabelecido a partir de uma documentação circunscrita - que nos cabe dar a ler ao público - e ainda "com a hipótese de que o que designamos como épocas históricas [...] constituem momentos singulares da existência das sociedades" (SILVA, 2015, p. 23).

Principiando pela conferência proferida por Buarque de Holanda, observamos que ele visou considerar a perspectiva em um só tempo distinta e próxima da quadra latino-americana da condição monárquica trasladada ao Novo Mundo em 1808. Naquele momento de 1963, este intelectual dizia que a herança colonial portuguesa ainda se fazia sentir, por vários motivos e sob inúmeros aspectos, mas acabou frisando apenas um deles, qual seja: o fato de o regime inaugurado em 1889 sequer ter assegurado condições de ingresso de muitos indivíduos ao jogo político, de sorte que, nesse sentido, o Império iniciado em 1822 teria sido um regime melhor. A tese é complexa, a saber: a época do Brasil Colônia era tão viva que, sob determinados ângulos, fizera das primeiras décadas republicanas uma cópia caricata de sua mentalidade, sendo esta mais conservadora em termos de acesso do povo aos destinos da nação do que defendeu ter sido o pensamento dominante nos decênios da Monarquia tropical.

Ademais, para mostrar como as personagens daquele momento viam a questão, Sérgio Buarque evocou, de um lado, Joaquim Nabuco (1849-1910), que no oitocentos fizera um paralelo com o Chile independente, muito parecido, em suas palavras no uso buarqueano, com a estabilidade política vivida no Segundo Reinado (1840-1889), mas sobretudo a partir de meados do século XIX. De outro lado, acionou diante dos vizinhos continentais o relato do naturalista norte-americano Herbert Huntington Smith (1851-1919) - velho conhecido desde seu livro de estreia, Raízes do Brasil (1936) -, que avaliara o tipo de sociedade passível de brotar

\section{CANPHLAC}

Revista Eletrônica da ANPHLAC, ISSN 1679-1061, N.27 , p. 347-378, Ago./Dez., 2019. http://revista.anphlac.org.br 
na região, caso fossem viabilizadas iguais possibilidades de instrução para toda a gente, conforme o seguinte trecho:

\begin{abstract}
Lo que precisa la América del Sur, son sus palabras, es una revolución; no una revolución horizontal, simple remolido de contiendas políticas, que sirven para atropellar algunas centenas o millares de personas poco afortunadas. El mundo está harto de tales movimientos. El ideal sería una buena y honesta revolución vertical que saque a la superfície los elementos más vigorosos, destruyendo para siempre a los viejos e incapaces. ¿De qué manera puede efectuarse esta revolución? Espero, responde el mismo Herbert Smith, que cuando llegue, surja plácidamente y venga a rematar la amalgama o el espurgo de las capas superiores que con todas sus faltas todavia cuentan con hombres de bien. Recordad que los brasileros están expiando actualmente tanto los errores de los padres como los suyos propios. Desde sus orígenes la sociedad estuvo mal formada en esta tierra. Si las clases cultas se hallan aisladas del resto de la nación no es por culpa de ellas o por su mala suerte. Me atrevo a afirmar que como clase, los obreros y comerciantes me parecen mejores que los caballeros y los ricos (HOLANDA, 1963, p. 39-40).
\end{abstract}

Destarte, nota-se que face à plateia do CIHA, Buarque de Holanda apropriou-se do depoimento de Herbert Smith para unir em ideias as três Américas e falar da urgência de uma Revolução não palaciana. Desse modo, era como se quisesse dizer que o Império do Brasil esteve mais perto dos governos instalados nos antigos domínios hispânicos, quando se processaram as Independências, que a República elaborada pelas Forças Armadas em fins do oitocentos. Ao assumir a postura de cidadão, talvez por isso fazendo as vezes de profeta, Sérgio Buarque de Holanda emitiu sua opinião a respeito do que corria em seu país no governo João Goulart (1961-1964). Com efeito, afirmou que acreditava no argumento de que a grande fratura da história contemporânea do Brasil nascia de um lento processo revolucionário, este sim horizontal, e sendo a Abolição um de seus pontos altos, mas que não poderia ser situada em 1889 ,

sino en 1930. [...]. Resultó primero una crisis de la idea liberal y en seguida una disolución creciente de las instituciones sociales y las formas de vida económica reinantes en el siglo pasado. Es ahora que la historia brasilera entra en una nueva órbita (HOLANDA, 1963, p. 40).

Nascido na cidade de São Paulo, em 1902, e morto nesta mesma capital, em 1982, convém sumarizar a trajetória de Sérgio Buarque de Holanda até o momento de sua conferência

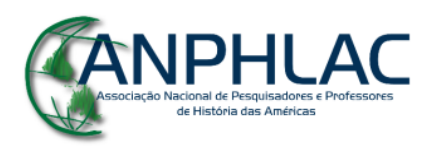

Revista Eletrônica da ANPHLAC, ISSN 1679-1061, №.27 , p. 347-378, Ago./Dez., 2019. http://revista.anphlac.org.br 
no Chile para melhor compreender o lugar a partir do qual ele falava e buscava se situar. Assim, é válido dizer que, em 1921, com pouco mais de 18 anos de idade, o jovem transferiu-se para o Rio de Janeiro, então Distrito Federal (DF), matriculando-se na Faculdade de Direito daquela que viria a ser a Universidade do Brasil (UB), formação esta que mal chegou a exercer. Ainda nos anos vinte se envolveu em discussões do movimento modernista, quando iniciou suas colaborações na imprensa, as quais, apesar de oscilatórias, manteria por quase toda a sua vida, sobretudo em periódicos do eixo Rio-São Paulo. No fim da década foi para a Alemanha como enviado especial d'O Jornal, de propriedade do magnata das comunicações, Assis Chateaubriand (1892-1968). De volta ao país, retornou às redações e em 1936 teve publicado seu primeiro texto na forma de livro, o já mencionado Raízes do Brasil, como o volume inicial da coleção intitulada Documentos Brasileiros, da Livraria José Olympio Editora (LJOE). Em 1939 começou a trabalhar no Instituto Nacional do Livro (INL) e no decênio seguinte assumiu a Divisão de Consultas da Biblioteca Nacional (BN). Deixou o Rio e retornou à cidade de São Paulo para ocupar o posto de historiógrafo, em 1946, e mais tarde, nos anos 1950, o de diretor do Museu Paulista. Além disso, tomou parte nas discussões sobre o conceito de democracia da Organisation des Nations Unies pour l'Éducation, la Science et la Culture (UNESCO), em 1949, na França. Antes, entre 1936 e 1939, lecionou História Moderna, Econômica e da Civilização Luso-Brasileira na Universidade do Distrito Federal (UDF). Com algumas interrupções, de 1947 a 1955, foi professor das disciplinas História Econômica, Social e Política do Brasil da Escola Livre de Sociologia e Política (ELSP) de São Paulo. No biênio 1952-1954, convidado para lecionar na Itália em meio aos esforços internacionais para difundir as culturas dos povos após a Segunda Guerra Mundial (1939-1945), foi docente de Estudos Brasileiros na Universidade de Roma. $^{5}$

No mesmo período foi professor de História do Brasil na Universidade de Sorocaba-SP e em 1956 passou a atuar na USP, até se tornar catedrático (1958) via concurso e ao defender a tese Visão do Paraíso: os motivos edênicos no descobrimento e colonização do Brasil, publicada pouco depois. Seus principais trabalhos em livros, até 1963, eram os títulos, antes

\footnotetext{
${ }^{5}$ Cf. Série: Vida Pessoal. 88 - Curriculum Vitae de SBH. 1958. Vp 88 P242. Fundo SBH. Siarq-UNICAMP.

\section{GANPHLAC}

Revista Eletrônica da ANPHLAC, ISSN 1679-1061, N.27 , p. 347-378, Ago./Dez., 2019. http://revista.anphlac.org.br
} 
citados, de Raízes do Brasil e Visão do Paraíso (saídos respectivamente em 1936 e 1959), e ainda: Cobra de vidro (1944); Monções (1945); \& Caminhos e fronteiras (1957).

Agora passemos à fala / ao texto de Ruggiero Romano que, em sua aula inaugural, apresentou questões interessantes. Em primeiro lugar, Romano levou os presentes a pensarem se seria salutar na análise da história novo-mundista, no exemplo em tela os tempos pretéritos da América espanhola, a utilização do aporte conceitual, bem como das terminologias e gramáticas europeias para se entender o passado do continente. Ou seja: sua preocupação inicial - conforme nos aponta a chamada de sua conferência (História de los precios e Historia colonial hispanoamericana), era com os estudos que se desenvolveram a respeito da economia no período supracitado que, segundo ele, estavam aferrados a concepções teóricas que eram válidas para a avaliação da Europa. Contudo, o aspecto que sinalizou consistia em pensar a história econômica hispano-americana tendo em mente um arcabouço específico que pudesse dar conta dos fatos ocorridos na América. Vale acompanhar sua comunicação / seu registro:

\footnotetext{
¿Tenemos la certeza de no estar errados en el aplicar a problemas de história americana una terminología, una gramática, una sintaxis conceptuales, construídas enteramente sobre el bagaje de la experiencia historiográfica europea? Digo esto porque me he convencido que es necesario, para dar una vida real a los estudios de historia de la economía sudamericana de la época colonial, rehacer, ex novo, los instrumentos intelectuales de base (ROMANO, 1963, p. 44).
}

Como se não bastasse, também questionou a utilização do conceito de Colônia para se referir às entidades americanas desde o século XVI. Dessa maneira, destacava uma corrente historiográfica defensora do argumento segundo o qual as particularidades de muitas regiões sob domínio de Castela, na América, de alguma forma não faziam desses lugares muito diferentes de territórios reinóis como Aragão, Valência ou Nápoles, face à autonomia local.

Por outro lado, enfatizou existirem historiadores confiantes de que os laços estabelecidos entre as possessões do ultramar em destaque e a pátria-mãe foram constitutivos de uma relação de dependência. Segundo Romano, essa conexão subordinada não era um vínculo constitucional, legislativo ou administrativo mediante os quais eventualmente podia-se fugir. Tratava-se, em realidade, de uma questão econômica que cobria toda a massa continental em apreço e se concretizava essencialmente como economia natural. Logo, a tese de Romano,

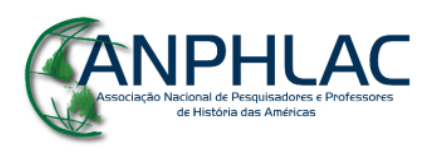

Revista Eletrônica da ANPHLAC, ISSN 1679-1061, N.27 , p. 347-378, Ago./Dez., 2019. http://revista.anphlac.org.br 
em consonância com as de outros historiadores à época, era de que esse status quo do solo colonial estava na contramão do desenvolvimento de uma economia de caráter monetário.

As interpretações feitas por Romano a esse respeito se encontram em harmonia com a tese do historiador Charles Verlinden (1907-1996), que, entre outros estudos publicados nas décadas de 1950 e 1960, destacou-se em Les origines coloniales de la civilisation atlantique. De la Renaissance à l'âge des lumières (1966). Neste estudo ele afirmou ser correta a análise acerca da existência da civilização oceânica à qual se referia o título de seu trabalho, fruto da confluência da Europa, das Américas e da África. Contudo, no livro supracitado Verlinden defendia em igual medida que se o século XVIII fora de grande importância para a solidificação desse mundo, seus princípios remontavam à Idade Média. Daí que Ruggiero Romano, em sua pesquisa posterior, denominada Les mécanismes de la conquête coloniale: les conquistadores (1972), reiteraria os argumentos sobre a feudalidade americana, pois esta já havia sido apresentada por Verlinden no estudo justamente intitulado Précédents médiévaux de la colonie en Amérique. Periode coloniale (1954).

Afinal, Romano entendia que

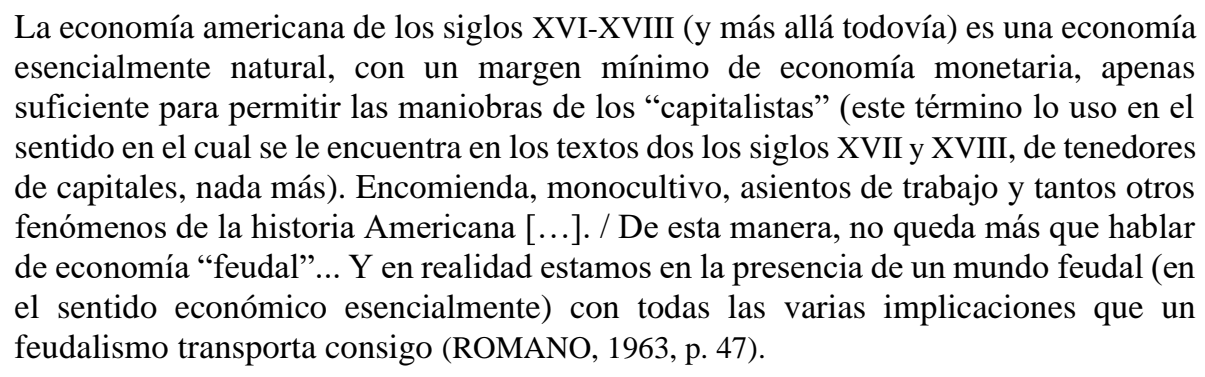

A partir daí ele defendeu a hipótese segundo a qual, no Novo Mundo, desenvolveu-se uma feudalidade americana que seria uma espécie de economia natural responsável por se consagrar em uma situação completamente diferente da experiência europeia, a saber: os direitos foram exercidos sobre sujeitos considerados racialmente distintos e carentes de evangelização. Tais indivíduos eram vistos, ademais, como inferiores no tocante às técnicas de produção.

\section{CANPHLAC}

Revista Eletrônica da ANPHLAC, ISSN 1679-1061, No.27 , p. 347-378, Ago./Dez., 2019. http://revista.anphlac.org.br 
Assim, para Romano, foi possível estabelecer nexos de opressão particularmente duradouras e rigorosas. Percebe-se, desse modo, que o palestrante indicou aí a presença de um laço, tendo inclusive se atentado à discrepância de caráter racial no encontro em tela, que teria projetado a confecção das sociedades novo-mundistas. Entretanto, isso corresponde a uma ideia a qual os estudos atuais vêm matizando, pois não se compreende mais que os primeiros contatos teriam estabelecido nitidamente aos europeus que os indígenas ou os africanos seriam de raças diferentes (SILVA, 2016). As dissemelhanças físicas, no processo de conquista e colonização das terras e gentes, não necessariamente redundavam em entender o outro como inferior. Tampouco os europeus consideravam as técnicas produtivas dos povos autóctones inferiores às suas em demasia.

Seja como for, Romano asseverou que a feudalidade desenvolvida na América teria outra característica basilar: ela não fora autônoma vis-à-vis à Europa. Em sua avaliação, correspondera a uma sociedade composta por grupos de grandes produtores que venderam barato para o Velho Continente os frutos de seus trabalhos, mas ainda assim precisavam comprar as mercadorias caras que vinham de lá. Dessa forma, não teria sido possível acumular capital nas mãos desses sujeitos e, portanto, existiram limitadas chances de se constituir uma classe burguesa a Ocidente do Atlântico. Por isso, o intelectual fez ecoar / anotou o seguinte:

\footnotetext{
Una burguesía supone, en efecto, una acumulación de capitales y ¿cómo acumular algo en un sistema de economía natural? / Es por esto que el apelativo colonial se ha encargado de un preciso significado: sistema de economía natural sin ninguna autonomía de decisión en las esferas más altas del poder económico (ROMANO, 1963, p. 51).
}

Destarte, uma burguesia supunha, argumentava o professor italiano, a acumulação de capitais e não se poderia dessa maneira proceder em um sistema de economia natural. $\mathrm{O}$ autor destacava, enfim, que os homens que partiram para a conquista e colonização da América haviam trazido um espírito feudal sem medida. Logo, percebe-se que as análises traçadas por Romano a respeito da economia nas terras americanas de jurisdição espanhola estavam em consonância com as teses do historiador Charles Verlinden, para quem as conexões do Novo Mundo com a Europa foram cruciais para se desenhar uma paisagem da Latino-América que, ao fim, seria uma extensão do Velho Continente, posto que do último quadrante teria adquirido

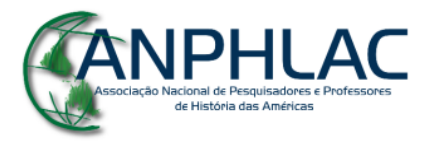

Revista Eletrônica da ANPHLAC, ISSN 1679-1061, №.27 , p. 347-378, Ago./Dez., 2019. http://revista.anphlac.org.br 
as feições e a cultura. Ou seja: a contribuição teria sido mais do espaço europeu e, nesse caso, sobretudo o período medieval era situado como o fundamento que viabilizaria a feitura, especialmente da porção ibérica desse território, de uma Nova Europa (VERLINDEN, 1953; 1954; 1966).

Portanto, Romano entendia que não se poderia falar de capitalismo quando das pesquisas sobre o sistema econômico colonial. Ao iniciar sua exposição conforme aparece em Tres lecciones inaugurales, não deixava de destacar a importância das investigações acerca da América Latina, desde as suas origens, com aportes conceituais distintos daqueles que se usavam para compreender o universo europeu. Por esse aspecto, nota-se que embora o italiano defendesse as continuidades, como queria Verlinden, não ficou preso à ideia segundo a qual a terra americana fosse uma espécie de continuum daquela da Europa. Para ele, era preciso considerar as especificidades latentes dentro das tentativas de se fazer uma História Atlântica.

Nesse passo, arrematou sua comunicação sinalizando que os trabalhos historiográficos, que à época se debruçavam sobre o estudo dos preços na América colonial lançando mão de instrumentos a exemplo de gráficos e tabelas, o faziam fragmentariamente e sem respaldo de fontes primárias suficientes para comprovar o que apresentavam. Romano ressaltava não ser apenas tal imprecisão de fins - por sua vez convertida em faltas - que havia conduzido a História dos preços ao impasse vivido naquele momento. Isso porque no seu entender tratavase de uma ausência de ideias econômicas gerais acerca de processos ocorridos no Novo Mundo. Com efeito, finalizou: "Ha sido por esta ausencia que se ha llegado a posiciones mecánicas y también mecanicistas. Las fórmulas, los esquemas, los modelos repetidos y repetidores han invadido la historia de los precios con demasiado éxito" (ROMANO, 1963, p. 55).

Face às mesmas razões que nos levaram a situar os estágios das trajetórias de Eugenio Pereira Salas e de Sérgio Buarque de Holanda até o tempo do encontro, em 1963, no Chile, fazse necessário repetir o procedimento com o historiador italiano Ruggiero Romano (1923-2002).

Logo, cabe inicialmente enfatizar o fato de ele ter obtido uma sólida formação em Filosofia e Letras (Universidade de Nápoles) e considerar que, sobretudo após seu encontro com Fernand Braudel (1902-1985) e o grupo da revista dos Annales a partir do ano de 1947, nos legou uma vasta obra que aborda especialmente os aspectos econômicos da hispano-América.

\section{CANPHLAC}

Revista Eletrônica da ANPHLAC, ISSN 1679-1061, №.27 , p. 347-378, Ago./Dez., 2019. http://revista.anphlac.org.br 
No decorrer de sua carreira, buscou destacar sua ascendência napolitana, ressaltando a educação ilustrada recebida, assim como a importância da sua família que, desde o século XVIII, teria feito parte de uma elite responsável por estudos cuja meta era levar tal conhecimento ao homem moderno. Sua cátedra em História Econômica em Paris foi conquistada por meio da EPHE, na qual passou a trabalhar em 1955. Nas décadas de 1960 e 1970, recebeu, por exemplo, estudantes peruanos que se doutoraram sob sua orientação, tais como: Heraclio Bonilla (1942-...), Juan Manuel Burga Díaz (1942-...) e Alberto Flores Galindo (1949-1990) (MARTíNEZ, 2001, p. 226).

Em entrevista concedida mais ao término de sua vida acadêmica, Romano deu a entender que seu interesse pela História da América resultou de acontecimentos fortuitos. Afinal, buscando escapar das mesmas curvas e indicadores econômicos europeus, passou a investigar o tema dos preços no Japão seiscentista, mas o problema era que as aulas no Institut de Langues Orientales implicavam entre quatro a cinco anos de estudos. Assim, quando o professor Camille-Ernest Labrousse (1895-1988) não pôde aceitar um convite de Mario Góngora del Campo (1915-1985), da Universidad de Chile, para ir a Santiago ministrar seminários sobre a Europa, Braudel o convocou para essa missão científica de 12 meses, que se repetiu nos dois anos seguintes. Note-se, aliás, que isso não se tratava de uma iniciativa da $V I^{e}$ Section da EPHE e, como o depoimento não precisa quando teria sido essa viagem, pode-se supor que ela fora anterior ao encontro de 1963, pois na mesma entrevista Romano informou que após tal período conheceu a Argentina em 1956, já no âmbito de interesses americanistas porque havia começado, por conta própria, a pesquisar os arquivos da capital chilena. Entretanto, a ida à cidade portenha foi intermediada por José Luis Romero (1909-1977), que dirigia a Universidad de Buenos Aires e, estando em Paris para uma Conferência Mundial de Reitores, comunicou a Romano seu acerto com Góngora del Campo para que seu destino naquele momento fosse outro país. A propósito de seu rechaço à expressão América Latina, o historiador italiano explicou que não era o caso apenas de evitar o eurocentrismo, mas também porque acreditava que seus termos, quando nasceram à época da expedição francesa no México, eram mais completos por acoplar a palavra "católica". Contudo, tratava-se de um instrumento da propaganda napoleônica. Seus usos, porém, vinculam-se, no seu dizer, antes ao ímpeto anti-inglês e antinorte-americano. Por isso, insistir na terminologia seria o mesmo que ignorar as dimensões

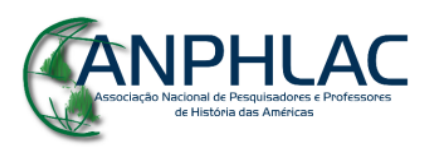

Revista Eletrônica da ANPHLAC, ISSN 1679-1061, №.27 , p. 347-378, Ago./Dez., 2019. http://revista.anphlac.org.br 
Indígenas e Negras do continente. Vale destacar ainda que a partir de 1961 Romano começou seus cursos na EPHE em História da América e em 1962 se tornou diretor do Centre de Recherches Historiques da VI Section (RINGUELET, 1991, p. 71-73 \& 75).

Até o ano em que realizou sua conferência em Santiago, suas publicações de maior relevo eram: Navires et marchandises à l'entrée du port de Livourne, 1547-1611 - em coautoria com Fernand Braudel (1951); Le commerce du royaume de Naples avec la France et les pays de l'Adriatique au XVIII siècle (1951); \& Commerce et prix du blé à Marseille au XVIII siècle (1956).

Considerados esses pontos, convém enfatizar a conferência de Max Savelle. Em El espíritu de la Independência Americana o professor estadunidense salientou a existência de uma onda revolucionária que teria varrido o Atlântico no século XVIII, sendo responsável por mudar a face do Ocidente. Tais pesquisas estavam em harmonia com aquelas apresentadas pelos historiadores Robert Roswell Palmer (1909-2002) e Jacques Godechot (1907-1989). Isso porque na década de 1950, estes últimos intelectuais se baseavam na lógica de que as ideias de liberdade das Revoluções Americana (1776) e Francesa (1789) tiveram papéis essenciais, pois teriam se espraiado e, dessa forma, chegado a diferentes regiões do globo terrestre, inclusive servindo de base para os processos independentistas da América Latina. Através dessa ótica, sobretudo no caso de Godechot, foi retomada a perspectiva da importância do ideário iluminista no bojo da emergência das novas nações.

Jacques Godechot e Robert Palmer são representativos de uma corrente historiográfica desenvolvida no pós-1945 que evocava a possibilidade de uma História Atlântica na qual se amarravam as diferentes partes do mundo, interligando-as pelo oceano em questão, particularmente em termos de desenvolvimento de uma mesma cultura política (BAILYN, 2003). Vale frisar, ademais, que Godechot e Palmer trabalharam juntos na Princeton University, entre 1954 e 1955.

Desses encontros e pesquisas, duas publicações são exemplares da busca pela reintrodução do ideário revolucionário nos movimentos que teriam se alastrado a partir do século XVIII. Por um lado, o título La grande nation: l'expansion revolutionnaire de la France dans le monde, 1789-1799 (1956), de Godechot, e, por outro, The age of democratic revolution: a political History of Europe and America, 1760-1800 (1959), de Palmer. De uma certa maneira,

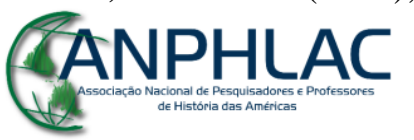

Revista Eletrônica da ANPHLAC, ISSN 1679-1061, N.27 , p. 347-378, Ago./Dez., 2019. http://revista.anphlac.org.br 
esses livros aplicavam aos tempos das independências o conceito de revolução por associá-las ao desdobramento do cenário francês de fins do setecentos e princípios da centúria subsequente. Portanto, os ecos sobretudo de Paris teriam ocasionado uma onda de ideias como as de liberdade ou democracia e, dessa forma, haviam funcionado como uma espécie de força irradiadora cujo potencial abarcara os dois lados do Atlântico.

Savelle também parece acreditar em uma avalanche revolucionária que teria se espraiado por todos os rincões do mundo em destaque. Não fosse isso, o conferencista não estabeleceria, ainda no início da sua fala / escrita, uma comparação entre os acontecimentos passados nas Treze Colônias e no Chile, como se os processos revolucionários de formação das nacionalidades em ambas as regiões fizessem parte de um ideário mais amplo que se espalhara pelo globo nos momentos derradeiros do século XVIII e no início do XIX. Mas, embora o professor estadunidense se inclinasse a pensar nessa Era democrática, ele não considerou os eventos da América do Norte como acontecimentos revolucionários tout court.

Nesse sentido, Max Savelle retirou o peso do viés econômico como questão fundamental para a ocorrência da Revolução Americana e destacou o papel das ideias políticas no processo. As questões desenvolvidas na própria Inglaterra aparecem nele reinterpretadas à luz do contexto das Treze Colônias. Para Savelle, o conceito de Nação Imperial Britânica era um fenômeno metafísico compartilhado, antes da crise americana, por múltiplas gerações inglesas através dos tempos e onde quer que residissem. Ou seja: a expressão também possuía uma existência transcendente. Nota-se aqui, portanto, que o historiador trilhou o caminho da historiografia cujo intuito era observar os acontecimentos vivenciados nos Estados Unidos como se não fossem um conjunto de experiências descoladas da pátria-mãe.

Assim, o palestrante frisou que em 1766, os americanos possuíam clareza de que seu líder era o rei inglês. Contudo, entendiam que o Parlamento britânico não possuía nenhum poder nas fronteiras da comunidade, pois as colônias deveriam ser conduzidas por uma legislatura própria. Logo, a sua principal tese era de que o conflito entre as terras do ultramar e a Inglaterra teria sido um enfrentamento conceitual, passível de se acompanhar no seguinte trecho:

Se ha de notar que este concepto de nación imperial británica era también un fenómeno metafísico compartido, antes de la crisis americana, por múltiples

\section{CANPHLAC}

Revista Eletrônica da ANPHLAC, ISSN 1679-1061, №.27 , p. 347-378, Ago./Dez., 2019. http://revista.anphlac.org.br 
generaciones de británicos a través de los siglos y dondequiera que residiesen y que, en dicho sentido, tenía también una existencia trascendente. [...]. Desafortunadamente para los norteamericanos, en el sentimiento y en el pensamiento de la mayoría de los ingleses, el ideal de una nación imperial británica estaba ligado en forma inseparable al princípio de una autoridad absoluta de Inglaterra sobre las colonias. Por ello, los teóricos norteamericanos, a fin de armonizar su creciente teoría de autogobierno, arraigada en la experiencia colonial, con el concepto de nación británica, promulgaron por primera vez en la historia de occidente la teoría de un imperio federal (SAVELLE, 1963, p. 71).

Ora, é muito interessante como a História das Ideias Políticas está presente nessas reflexões. Tanto que, mais ao fim do registro de sua conferência, Max Savelle sublinhou que a luta pela independência nos Estados Unidos da América teria sido uma batalha de doutrinas, um choque entre duas teorias: uma de matriz britânica, da nação imperial indivisível; e a outra de caráter independentista, das antigas colônias, que abarcava inúmeros ideários que se voltavam aos horizontes da liberdade. Para Savelle, os homens lutavam pela posse das coisas, fosse um tesouro ou uma mulher, como Helena de Tróia. No caso por ele discutido, entretanto, da Guerra da Independência estadunidense, os combates eram

al igual por motivos económicos, sociais y religiosos y por el poder político. Pero también lidiaron por la realización de sus ideales y de sus aspiraciones, por estos bienes metafísicos que son de primordial importancia en la vida y en la historia de los hombres y de las naciones (SAVELLE, 1963, p. 75).

Assim, pode-se inferir que as teses defendidas por esta última palestra na capital chilena são representativas de uma geração que, na década de 1960, passava a usar o oceano com mais frequência em seus trabalhos, tomando-o como uma legítima instituição social, política, econômica e cultural de trânsitos humanos. Com isso, buscavam afirmar a existência de uma Civilização Atlântica que teria tomado escopo no século XVIII e, em especial, a partir dos movimentos revolucionários desse período. Desta feita, as colônias inglesas na América do Norte teriam sido exemplares de um renovado conjunto de ideais que, embora relacionados às ideologias da pátria-mãe, teriam tomado outro rumo em solo novo-mundista.

Provavelmente uma das avaliações mais veiculadas à época, expressiva no que tange ao nosso tema, seja o livro do historiador Bernard Bailyn intitulado The ideological origins of the American Revolution (1967). Nesse estudo é destacado que o objetivo mais importante do

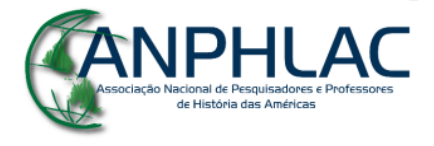

Revista Eletrônica da ANPHLAC, ISSN 1679-1061, №.27 , p. 347-378, Ago./Dez., 2019. http://revista.anphlac.org.br 
movimento independentista ao Norte não era a subversão ou tampouco a alteração da ordem social existente, mas sim "a preservação da liberdade política ameaçada pela aparente corrupção da constituição e o estabelecimento em princípio das condições vigentes de liberdade" (BAILYN, 2003, p. 37).

Para além de seu envolvimento, direta ou indiretamente, em todos esses debates, é preciso evocar alguns elementos da trajetória de Max Hicks Savelle (1896-1979), que era da região estadunidense do Alabama. Ele cursou o ensino médio na Barton Academy (Mobile) e se graduou em 1912. Alistou-se na Marinha em 1918 e após 1919, frequentou o Springfield College, em Massachusetts. Sua formação foi concluída na Columbia University, onde conquistou os títulos de Mestre (1926) e Doutor (1932). Ainda nessa instituição, atuou como colaborador na área de História e pouco depois se mudou para a Stanford University, onde se tornou um notável pesquisador em História da diplomacia americana e da América inglesa colonial. Em 1941, foi promovido ao cargo de professor e em 1947 chegou à UW, na qual ficaria até 1967 (depois desse ano seria professor Emérito), tendo desenvolvido estudos seminais para o conhecimento do passado acerca dos domínios britânicos no Novo Mundo. Ele viajou para a Europa através da Ásia e passou vários meses realizando pesquisas principalmente na França, mas também na Espanha, Alemanha e Grã-Bretanha. Tirou uma licença da UW em 1950, quando foi premiado com um Fulbright para realizar pesquisas adicionais no território francês. Em 1957, por conta de dificuldades financeiras maiores, Savelle recusou um segundo fomento que o apoiaria em viagem a Santiago, junto à Universidad de Chile, para estabelecer um programa de civilização americana. No biênio 1960-1961, novamente se despediu da UW e foi lecionar na Universidad de Madrid, Espanha (MAX Savelle papers..., 2019).

Antes de sua volta ao Chile para ministrar sua palestra e o curso no CIHA, em 1963, seus principais estudos então publicados eram: The diplomatic history of the Canadian Boundary (1940); \& Seeds of liberty (1948).

Isto posto, torna-se incontornável ensaiar algumas conclusões, ainda que provisórias, acerca dos objetos de estudos e abordagens no âmbito da História da Américas proferidos em Santiago. Uma rápida análise sobre os três exemplos de teses que pudemos oferecer ao longo dessas páginas talvez possa sugerir que as falas / textos de Sérgio Buarque de Holanda,

\section{CANPHLAC}

Revista Eletrônica da ANPHLAC, ISSN 1679-1061, Nº.27, p. 347-378, Ago./Dez., 2019. http://revista.anphlac.org.br 
Ruggiero Romano e Max Hicks Savelle soem obsoletos hoje, mas enfatizamos que tais pensamentos não o eram na ocasião em que foram escritos e verbalizados. Estamos falando, nunca é demais recordar, do ano de 1963, quando a pauta da monarquia brasileira, no caso de Sérgio Buarque, mal havia se desenvolvido no interior das universidades, antes afeitas aos estudos sobre o passado dito colonial. E é razoável supor que, por esse motivo, ele optasse por uma interpretação atenta às heranças dessa época, levando-o a salientar a presença de suas estruturas para além do período Imperial (FURTADO, 2018). Isso teria inclusive chegado a minar a República no Brasil (HOLANDA, 1972; HOLANDA, 1979).

Também o revisionismo do viés econômico, conforme o apontou Romano, pouco se esboçava de forma nítida, de modo que sua análise ao mesmo tempo anunciava uma novidade e parecia apegada às pesquisas, muito em voga, sobre um prolongamento da Idade Média. Esta última ótica, embora venha a se firmar plenamente apenas nos anos 1970-1980 (LE GOFF, 1979; 2004), sustentou a continuidade do medievo sobre a modernidade e cujo término se daria só com o advento da indústria e das enciclopédias. Para tanto, tais ideias se fundamentaram, entre outros, em Eugênio Garin (1909-2004), que na década de 1950, havia convocado os historiadores a reavaliarem as depreciações aí verificadas, como a imagem de Idade das Trevas (COPPES, 2015).

Por fim, e não menos importante - apesar de, ao que tudo indica, estar mais relacionado a uma History of Ideas -, vale frisar que enquanto o estadunidense Max Savelle falava em motivos metafísicos no processo independentista das Treze Colônias, emergia o programa francês de Histoire des Mentalités. E embora a História das Ideias e a das Mentalidades não sejam sinônimas, é ponto pacífico o entendimento de que esta ("francesa") foi uma reelaboração daquela ("americana"). Aliás, foi justamente entre o fim de 1950 e o início da década seguinte que a historiografia produzida na França passou a reunir referências teórico-metodológicas para criar essa nova vertente disciplinar, bebendo "tanto na caracterização fundamentalmente psicológica da mentalidade coletiva quanto na redefinição do que deve ser a história das ideias, ressituada numa exploração global do mental coletivo" (CHARTIER, 2002, p. 37). Nesse sentido de trocas letradas Norte-Sul e Leste-Oeste, convém enfatizar, aliás, que particularmente sobre

\section{CANPHLAC}

Revista Eletrônica da ANPHLAC, ISSN 1679-1061, №.27 , p. 347-378, Ago./Dez., 2019. http://revista.anphlac.org.br 
a atuação franco-estadunidense no Brasil, há cerca de trinta anos já dispomos de estudos dedicados ao tema, sobretudo pelo viés institucional e disciplinar (MASSI, 1989).

Faz-se mister salientar, porém, que a palavra mentalidade circulava desde o início do século XX na linguagem comum para qualificar comportamentos, e na de caráter científico como no viés etnológico de Lucien Lévy-Bruhl (1857-1939), que analisou em Les fonctions mentales dans les sociétés inférieures (1910) e em La mentalité primitive (1922), os aspectos chamados de pré-lógicos. Sua tese atentava aos traços comportamentais de grupos negligenciados, como os de autóctones ou crianças. Porém, entre os historiadores propriamente isso somente ocorreria a partir dos decênios de 1920 e 1930, em trabalhos como os de Marc Bloch (1886-1944) e Lucien Febvre (1978-1956). O problema nessa incerteza de definição se explicitaria quando alguns entendimentos passaram a encará-la como área de estudos mais propriamente históricos, após os anos 1950 (REVEL, 1993, p. 529).

Assim, o olhar panorâmico sobre as porções continentais tratadas pelos três historiadores aqui recuperados, provavelmente de forma inédita, que se reuniram no CIHA, concentra indícios eloquentes dessas renovações historiográficas. Se tais pronunciamentos em Santiago do Chile resultaram em outros laços acadêmicos, é algo que seguimos investigando. Isso porque, ao menos quanto a Sérgio Buarque de Holanda, notamos que após o convite de Eugenio Pereira Salas, outros acabaram lhe sendo feitos para ministrar cursos e proferir conferências em instituições estrangeiras via intercâmbios culturais. Estes aconteceram por iniciativa do embaixador americano no Brasil, Lincoln Gordon (1913-2009), e/ou de professores - estadunidenses ou não - que lhe relatavam o interesse das universidades por seu país e informavam quais estruturas se dispunham a recebê-lo. Exemplo disso é a carta do historiador Bradford Burns (1932-1995), que destacou:

The University offers courses on Brazilian history and geography and sponsors one of the seven Portuguese language centers in this country. I am writing you now to find out if you would be interested in an invitation and when. At your convenience, we will be pleased to extend the official invitation. ${ }^{6}$

\footnotetext{
${ }^{6}$ Série: Correspondência. Subsérie: Passiva. 490 - Carta em inglês de E. Bradford Burns da Universidade da Califórnia a SBH convidando-o para que fizesse uma visita à UCLA. Los Angeles, 15 mar. 1965. as. E. Bradford Burns. 1p. Cp 268 P10. Fundo SBH. Siarq-UNICAMP.
}

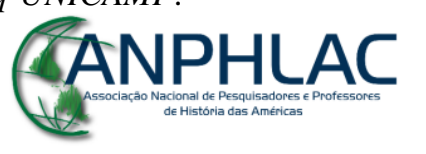

Revista Eletrônica da ANPHLAC, ISSN 1679-1061, Nº.27, p. 347-378, Ago./Dez., 2019. http://revista.anphlac.org.br 
Nesse mesmo ano, portanto, o brasileiro viajou aos Estados Unidos para realizar suas conferências. Visitou as Universidades de Columbia e Harvard (nas quais participou do VI Colóquio Internacional de Estudos Luso-Brasileiros), bem como as da Califórnia, Los Angeles e de Yale, integrou uma banca de doutoramento e orientou seminários.

Ora, os laços estavam feitos e talvez a urdidura decisiva tenha acontecido na conexão chilena. Esse nexo é pleno de significados nos desdobramentos que envolviam a porção latina do continente. Afinal de contas, em meio aos processos de modernização historiográfica e, no caso, de busca por certa autonomia mais ou menos relativa no campo acadêmico, foi possível verificarmos na iniciativa do CIHA um exemplo eloquente desses esforços, pois tal movimento visava estabelecer contatos e agendas comuns de pesquisa.

O encontro entre Buarque de Holanda, Romano e Savelle intermediado por Pereira Salas foi marcado pelo que havia de melhor e recente na produção intelectual do Ocidente. A meta tinha por fim o fomento de outras possibilidades investigativas e a produção de trabalhos de igual rigor e originalidade daqueles que, via de regra, seguiam atrelados sobretudo aos estudos desenvolvidos em regiões ao Norte do globo. Por isso, arriscamo-nos a inferir que naquelas missivas de 1962-1963 estavam incutidos os planos de tentar, em um só tempo, a intensificação de diálogos já existentes, em particular com os países da Europa - notadamente a França, na qual atuava o italiano Ruggiero Romano - e com os Estados Unidos - pátria de Max Hicks Savelle.

Entretanto, a presença do brasileiro Sérgio Buarque de Holanda, por sua vez, pode ser vista como a aposta chilena para mandar o seguinte recado: buscava-se o estabelecimento de um leque de pesquisas inovadoras que pudessem contribuir para fazer circular suas ideias na renovação dessas redes internacionais. Porém, a linha mestra desse intuito não se direcionava a assumir um papel de mera receptora de perspectivas estrangeiras por ventura sopradas dos centros de produção historiográfica: propunha-se, em vez disso, inverter o sinal, ou seja, construir uma agenda protagonista de estudos universitários a partir do cone Sul.

E o exemplo maior disso vinha da própria Universidad de Chile, em uma espécie de préhistória do CIHA. Ocorre que em 1956 Rolando Mellafe Rojas (1929-1995) - cujo mestre era

\section{CANPHLAC}

Revista Eletrônica da ANPHLAC, ISSN 1679-1061, №.27 , p. 347-378, Ago./Dez., 2019. http://revista.anphlac.org.br 
Pereira Salas - registrou que desejava ir à Paris para investigar e dialogar com o também historiador Fernand Braudel sobre questões da economia chilena no cenário americano. Por esse viés, buscava inserir tal debate na sua relação com o oceano Pacífico, por ele apontado como unidade espaço-temporal em referência ao trabalho sobre o Mediterrâneo, publicado em 1949 e logo traduzido pelo Fondo de Cultura Económica (FCE) para o espanhol (BRAUDEL, 1953). Sobre a importância dessa casa editorial nos processos acadêmicos cá analisados, já existem pesquisas que a avaliam como divisora de águas porque decisiva no estabelecimento de um repertório de referências bibliográficas que transformariam os debates nos espaços intelectuais das porções hispanohablante e portuguesa do continente, dando maior visibilidade às produções latino-americanas (SORÁ, 2010).

Vale frisar, entretanto, que para além das aproximações com integrantes dos Annales, Mellafe Rojas ajudou a desenvolver o projeto de criação do Centro de Investigaciones na capital, que contou em sua emergência com o apoio financeiro de instituições estadunidenses. Posto em atividades em 1962, o plano não tardou a malograr, entre outros fatores devido a querelas internas e em virtude dos movimentos de radicalização política (SILVA, prelo). Este último fator redundou no rechaço dos investimentos externos pelos estudantes (temerosos e críticos, à época, do chamado domínio imperialista) e na deflagração de golpes de Estado por toda a América Latina (MOTTA, 2014; ROLLEMBERG; QUADRAT, 2010). Mesmo assim, convém destacar que um tipo de empenho institucional semelhante ocorria no mesmo período no Brasil - e que perdura até hoje. Afinal, não podemos esquecer do Instituto de Estudos Brasileiros (IEB) da USP, o qual Buarque de Holanda foi um dos fundadores e seu primeiro diretor, também a partir desse mesmo ano de 1962.

Mas voltando ao princípio dessa discussão, ou seja, o momento do convite, convém retornar alguns pontos que guardamos especialmente para esse fim. Acontece que na correspondência trocada entre Eugenio Pereira Salas e Sérgio Buarque de Holanda, vimos como este optou pelo tema intitulado Brasil Império. Diante disso, Pereira Salas o saudava com alegria. No seu registro epistolar, não se tratava só de um assunto "de alto valor por el tratamiento historiográfico [...] sino tambien porque" a temática "toca[va] un punto en las

\section{CANPHLAC}

Revista Eletrônica da ANPHLAC, ISSN 1679-1061, №.27 , p. 347-378, Ago./Dez., 2019. http://revista.anphlac.org.br 
vinculaciones americanas particularmente gratas a Chile", ${ }^{7}$ que já abordamos. Ao término, o diretor do CIHA anunciava ao brasileiro que destacariam um aluno para auxiliá-lo e que a embaixada lhe daria todo o suporte enquanto ficasse no país. Recomendava ainda o professor Rolando Mellafe Rojas - o mesmo da referência ao Mediterrâneo, de Braudel - para ciceroneálo quando ele, Salas, estivesse ausente. ${ }^{8}$

Em uma dessas cartas que detalhavam os procedimentos e condições, Pereira Salas a finalizou com a seguinte anotação: "En la biblioteca del Centro poseemos los volúmenes 1 y 2 de la Historia da Civilização Brasileira que Ud. dirije. Necessitamos si de antemano una bibliografía de los libros que empleará Ud. para conseguirlos en caso que no los tengamos". 9 Esse pedido foi prontamente atendido, de modo que o número faltante da coleção e a lista de outros títulos mais a serem adquiridos seguiram viagem com grande celeridade. ${ }^{10}$

$\mathrm{O}$ empreendimento editorial em destaque teve duas fases. A primeira buarqueana, na qual foram editados os seguintes volumes: Do descobrimento à expansão territorial \& Administração, economia, sociedade, do Tomo I (A Época Colonial) e ambos publicados em 1960; bem como O processo de emancipação (1962), Dispersão e unidade (1964), Reações e transações (1967), Declínio e queda do Império (1971) e Do Império à República (1972) do Tomo II (O Brasil Monárquico). E uma segunda, sob a gerência de Boris Fausto, ex-orientando de doutorado de Sérgio Buarque de Holanda na USP, que ficou responsável pelos seguintes livros: Estrutura de poder e economia (1889-1930), impresso em 1975; Sociedade e instituições (1889-1930), em 1977; Sociedade e política (1930-1964), em 1981; e Economia e cultura (19301964), em 1984. A cronologia histórica à época implementada pelo projeto coletivo em destaque buscou não ultrapassar o golpe civil-militar de 1964, no Brasil, quando o presidente João Goulart foi deposto. Em entrevista posterior, Fausto chegou a dizer, aliás, que alguns colaboradores "transgrediram" tal recorte temporal, pois avançaram sobre temas propriamente dos anos 1970 (FURTADO, 2016).

\footnotetext{
${ }^{7}$ Série: Correspondência. Subsérie: Passiva. 476 - Carta em espanhol de Eugenio Pereira Salas a SBH tratando de detalhes sobre o Curso de História do Brasil. Santiago do Chile, 04 abr. 1963. as. ileg. 1p. Cp 254 P9. Fundo SBH. Siarq-UNICAMP.

${ }^{8}$ Série: Correspondência. Subsérie: Passiva. 476, op. cit., 1p. Cp 254 P9. Fundo SBH. Siarq-UNICAMP.

${ }^{9}$ Idem.

${ }^{10}$ Série: Correspondência. Subsérie: Passiva. 480, op. cit., Cp 258 P9. Fundo SBH. Siarq-UNICAMP.
}

\section{GANPHLAC}


Duplamente significativo, os fatos supracitados convergem com os argumentos aqui defendidos pelas seguintes razões: I) o projeto em apreço, ou seja, a coleção História Geral da Civilização Brasileira (HGCB) - cuja publicação seguia em curso pela Difusão Europeia do Livro (Difel), desde 1960 -, integrava o conjunto de planos editoriais responsáveis pela renovação dos estudos históricos no Brasil e na América Latina (VENANCIO; FURTADO, 2016) \& 2) os professores chamados para atuarem no Chile, via CIHA, possuíam ou possuiriam conexões com projetos dessa natureza, como no caso de Romano e a vindoura Storia d'Italia, em doze volumes (ROMANO; VIVANTI, 1972-1989); e de Savelle, com A history of world civilization (SAVELLE, 1956-1957). Sendo que este último empreendimento editorial surgiu ao tempo das negociações da Difel para que Buarque de Holanda organizasse aquele que ficou sob a sua incumbência e, uma vez ingressado de forma definitiva na cátedra, auspícios da USP.

Logo, tal como as pistas deixadas por Mellafe Rojas - desejoso em estudar com Braudel -, ou o próprio Romano - que trabalhava com ele -, mantinham-se explícitos nesses projetos livrescos outros laços com o viés das civilizações que a Revue des Annales, então dirigida pelo autor das teses sobre a longue durée, passou a adotar em sua denominação a partir de 1946. No seu lançamento, em 1929, o nome do periódico era: Annales d'Histoire Économique et Sociale, já uma década depois, circulou como: Annales d'Histoire Sociale. Em alguns momentos dos anos 1940, sobretudo durante a ocupação nazista na França, utilizaram Mélanges d'Histoire Sociale, porém, a direção de Braudel o alterou para: Annales. Économies, Sociétés, Civilisations, assim permanecendo até 1994, quando foram adotados os termos atuais: Annales. Histoire, Sciences Sociales (BURKE, 1991). Evidentemente que em 1946 não se tratava do cenário pós-Primeira Guerra Mundial (1914-1918), quando o Comité International de Sciences Historiques (CISH / Paris) recomendava a fuga de perspectivas, no ensino e na pesquisa, que valorizassem o aspecto político ou o culto a personalidades. Mas vale relembrar esse debate, pois até meados do século $\mathrm{XX}$, pensar marcos civilizatórios de algum país em vez de em determinados espaços e no plural poderia despertar pendores ufanistas e/ou xenófobos dos quais o mundo já não tinha dúvidas após os horrores perpetrados entre 1939 e 1945, dos holocaustos e uso das bombas atômicas. É sob esse clima que se questionaram decisivamente as narrativas

\section{CANPHLAC}

Revista Eletrônica da ANPHLAC, ISSN 1679-1061, №.27 , p. 347-378, Ago./Dez., 2019. http://revista.anphlac.org.br 
europeias sobre a História da América por meio de um conjunto de estudos que mantinham tais diálogos, embora se autonomizando do ponto de vista acadêmico.

Seja como for, é válido sublinhar que esse aspecto da paulatina consolidação do mundo universitário latino-americano da segunda metade do século $\mathrm{XX}$ - que pode muito bem ser entendida e identificada com o pós-Segunda Guerra Mundial - emerge feito uma espécie de chave que permite dar a ler aqui as diversas conexões historiográficas cuja ênfase recaiu sobre os nexos estabelecidos nos países do hemisfério Sul. Não descuidando, portanto, das configurações que envolveram a UNESCO e seus desdobramentos para consolidar investigações nas áreas das Ciências Sociais e Humanas em todo o continente. Entretanto, sem observar o conjunto de aspectos e só a partir disso chegar a conclusões como essas, seria o mesmo que tomar o episódio em destaque e as vicissitudes de caráter biográfico-editoriais dos historiadores envolvidos como naturais ou imanentes.

Em outras palavras, proceder mediante outro modus operandi corresponderia a simplificar o complexo do plano de modernização historiográfica mais ou menos alinhavado como exclusivo dessas trajetórias intelectuais e, em consequência, estaríamos incorrendo em ilusões biográficas. Os pressupostos operacionais dessa expressão enfatizam que não é viável buscar compreender uma vida por intermédio de certo isolamento social diante dos acontecimentos que a circundam, sem outras vinculações com o seu entorno, pois isso "é quase tão absurdo quanto tentar explicar a razão de um trajeto de metrô sem levar em conta a estrutura da rede, isto é, a matriz das relações objetivas entre as diferentes estações" (BOURDIEU, 2005, p. 189-190). Daí nosso cuidado em apontar seus laços com este movimento acadêmico, bem como os elos entre seus agentes, instituições, projetos livrescos, pautas intelectuais e posicionamentos, com o fito de tentarmos escapar - bem ou mal - dessa armadilha.

Infelizmente, muitos desses processos sofreram abalos, como apontamos - entre outros fatores a serem investigados -, pelas ditaduras civil-militares que se instalariam no Brasil, no Chile, na Argentina... Mas, à guisa da epígrafe, é possível supor que o diagnóstico lúcido dos historiadores reunidos em Santiago reverberou em novidades que seduziam e, sobretudo, assustaram seus contemporâneos. Não tanto os da comunidade acadêmica, é claro, antes os dos governos ilegítimos. Mesmo assim, vale sublinhar que apesar desses percalços o movimento

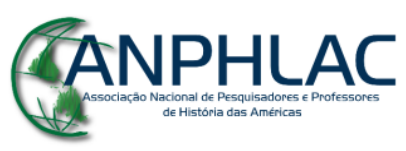

Revista Eletrônica da ANPHLAC, ISSN 1679-1061, №.27 , p. 347-378, Ago./Dez., 2019. http://revista.anphlac.org.br 
historiográfico então proferido em 1963 se converteu em um lance universitário irreversível: as pesquisas atingiram uma pauta própria que sequer os regimes de exceção destruiriam, a despeito dos nítidos pendores a um nacionalismo que estes últimos iriam estimular. Isso porque a América, em sua integralidade ou em partes, tinha se tornado um objeto de estudo dileto.

\section{Referências Bibliográficas}

\section{Fontes}

EL historiador da la cultura chilena, Eugenio Pereira Salas (1904-1979). In: Memoria chilena. Biblioteca Nacional de Chile (BNC). Disponível em: <http://www.memoriachilena.cl/602/w3article-618.html>.

HOLANDA, Sérgio Buarque de. Raízes do Brasil. Coleção "Documentos Brasileiros" (v. 1). Rio de Janeiro: José Olympio, 1936.

. Cobra de vidro. Coleção "Mosaico" (v. 5). São Paulo: Martins, 1944.

Brasil, 1945.

Monções. Coleção "Estudos Brasileiros" (v. 3). Rio de Janeiro: Casa Estudante do

Caminhos e fronteiras. Coleção "Documentos Brasileiros" (v. 89). Rio de Janeiro: José Olympio, 1957.

Visão do Paraíso: os motivos edênicos no descobrimento e colonização do Brasil.

Coleção "Documentos Brasileiros” (v. 107). Rio de Janeiro: José Olympio, 1959.

(org.). História Geral da Civilização Brasileira (t. I). Do descobrimento à expansão territorial (v. 1). São Paulo: Difel, 1960.

(org.). História Geral da Civilização Brasileira (t. I). Administração, economia, sociedade (v. 2). São Paulo: Difel, 1960.

(org.). História Geral da Civilização Brasileira (t. II). O processo de emancipação (v.

1). São Paulo: Difel, 1962.

\section{CANPHLAC}

Revista Eletrônica da ANPHLAC, ISSN 1679-1061, N.27 , p. 347-378, Ago./Dez., 2019. http://revista.anphlac.org.br 
HOLANDA, Sérgio Buarque de; ROMANO, Rugierro; SAVELLE, Max. Tres lecciones inaugurales. Santiago do Chile: Centro de Investigaciones de Historia Americana (CIHA) / Universidad de Chile, 1963. Centro de Apoio à Pesquisa em História. Faculdade de Filosofia, Letras e Ciências Humanas (CAPH-FFLCH) da Universidade de São Paulo (USP).

HOLANDA, Sérgio Buarque de. Brasil Império. In: ; ROMANO, Rugierro; SAVELLE, Max. Tres lecciones inaugurales. Santiago do Chile: Centro de Investigaciones de Historia Americana (CIHA) / Universidad de Chile, 1963. CAPH-FFLCH / USP.

(org.). História Geral da Civilização Brasileira: (t. II). Dispersão e unidade (v. 2). São Paulo: Difel, 1964.

(org.). História Geral da Civilização Brasileira (t. II). Reações e transações (v. 3). São Paulo: Difel, 1967.

. História Geral da Civilização Brasileira (t. II). Do Império à República (v. 5). São Paulo: Difel, 1972.

. Uma república não-proclamada (I, II \& III). Jornal da República. São Paulo, 17, 19 \& 20 nov. 1979. Hemeroteca da Fundação Biblioteca Nacional (FBN).

MAX Savelle papers, 1925-1977. Archives West (UW). Disponível em: <http://archiveswest.orbiscascade.org/ark:/80444/xv27014>.

ROMANO, Ruggiero; BRAUDEL, Fernand. Navires et marchandises à l'entrée du port de Livourne, 1547-1611. Paris: Armand Colin, 1951.

ROMANO, Ruggiero. Le commerce du royaume de Naples avec la France et les pays de l'Adriatique au XVIII siècle. Paris: Armand Colin, 1951.

Commerce et prix du blé à Marseille au XVIII siècle. Paris: Armand Colin, 1956.

. História de los precios e Historia colonial hispano-americana. In:

HOLANDA, Sérgio Buarque de; SAVELLE, Max. Tres lecciones inaugurales. Santiago do Chile: Centro de Investigaciones de Historia Americana (CIHA) / Universidad de Chile, 1963. CAPH-FFLCH / USP.

1972.

Les mécanismes de la conquête coloniale: les conquistadores. Paris: Flammarion,

; VIVANTI, Corrado. Storia d'Italia. Torino: Einaudi, 1972-1989.

SALAS, Eugenio Pereira. Los orígenes del arte musical en Chile. Santiago: s./ed., 1941.

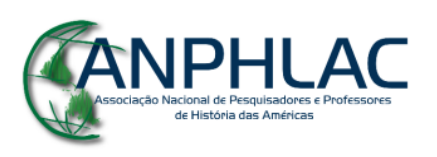

Revista Eletrônica da ANPHLAC, ISSN 1679-1061, №.27 , p. 347-378, Ago./Dez., 2019. http://revista.anphlac.org.br 
. Apuntes para la historia de la cocina chilena. Santiago: Imprenta Universitaria, 1943. . Juegos y alegrías coloniales en Chile. Santiago: Zig-Zag, 1947.

- Guía bibliográfica para el estudio del folklore chileno. Santiago: Instituto de Investigaciones Musicales - IIM, 1952.

América del Sur: Perú, Bolivia, Paraguay, Argentina, Chile: periodo nacional. Ciudad de México: Comisión de Historia, 1956.

Historia de la música en Chile: 1850-1900. Santiago: Universidad de Chile, 1957.

SAVELLE, Max. The diplomatic history of the Canadian Boundary. New Haven: Yale University Press: 1940.

. Seeds of liberty. New York: Alfred A. Knopf, 1948.

(ed.). A history of world civilization (2 vols.). New York: Holt, 1956-1957.

El espíritu de la Independência Americana. In: ; HOLANDA, Sérgio Buarque de; ROMANO, Rugierro. Tres lecciones inaugurales. Santiago do Chile: Centro de Investigaciones de Historia Americana (CIHA) / Universidad de Chile, 1963. CAPH-FFLCH / USP.

Série: Correspondência. Subsérie: Passiva. 470 - Carta em espanhol de Eugenio Pereira Salas a SBH, convidando-o para que ministrasse um curso sobre História do Brasil no Centro de Investigaciones de História Americana (CIHA). Santiago do Chile, 14 dez. 1962. as. ileg. 1p. Cp 248 P9. Fundo "Sérgio Buarque de Holanda" (SBH). Sistema de Arquivos da Universidade Estadual de Campinas (Siarq-UNICAMP).

476 - Carta em espanhol de Eugenio Pereira Salas a SBH tratando de detalhes sobre o Curso de História do Brasil. Santiago do Chile, 04 abr. 1963. as. ileg. 1p. Cp 254 P9. Fundo SBH. Siarq-UNICAMP.

480 - Carta em espanhol de Eugenio Pereira Salas a SBH avisando-o que recebeu sua carta e o espera a fim de organizasse as classes do curso de História do Brasil e preparasse uma aula inaugural onde seria feito um resumo do curso. Santiago do Chile, 16 set. 1963. as. ilegível. 1p. Cp 258 P9. Fundo SBH. Siarq-UNICAMP.

490 - Carta em inglês de E. Bradford Burns da Universidade da Califórnia a SBH convidando-o para que fizesse uma visita à UCLA. Los Angeles, 15 mar. 1965. as. E. Bradford Burns. 1p. Cp 268 P10. Fundo SBH. Siarq-UNICAMP.

\section{CANPHLAC}

Revista Eletrônica da ANPHLAC, ISSN 1679-1061, №.27 , p. 347-378, Ago./Dez., 2019. http://revista.anphlac.org.br 
Série: Vida Pessoal. 88 - Curriculum Vitae de SBH. 1958. Vp 88 P242. Fundo SBH. SiarqUNICAMP.

\section{Bibliografia}

ARRANGO, Diana Soto. La enseñanza ilustrada en las universidades de América colonial. Estudio historiográfico. In: ___ et. al. La ilustración en América colonial. Madrid: Ediciones Doce Calles / CSIC / Colciencias, 1995.

BAILYN, Bernard. The ideological origins of the American Revolution. Cambridge: Harvard University Press, 1967.

As origens ideológicas da Revolução Americana. Bauru: Edusc, 2003.

BARNADAS, Josep. La Iglesia católica en la hispanoamérica colonial. In: BETHELL, Leslie (ed.). Histora de América Latina (v. 2). Barcelona: Editorial Crítica, 1990.

BOURDIEU, Pierre. Os usos sociais da ciência: por uma sociologia clínica do campo científico. São Paulo: Ed.Unesp, 2004.

A ilusão biográfica. In: FERREIRA, Marieta de Moraes; AMADO, Janaína (orgs.). Usos e abusos da história oral. 6.ed. FGV, 2005.

BRAUDEL, Fernand. La Méditerranée et le monde méditerranéen à l'époque de Philippe II [1947]. Paris: Librairie Armand Colin, 1949.

El Mediterráneo y el mundo mediterráneo en la época de Felipe II. Colección "Historia". Cidade do México / Madrid / Buenos Aires: Fondo de Cultura Económica (FCE), 1953.

BURKE, Peter. A Revolução Francesa da historiografia: a Escola dos Annales, 1929-1989. São Paulo: Ed.Unesp. 1991.

CERTEAU, Michel de. A escrita da história. Rio de Janeiro: Forense Universitária, 1982.

CHARTIER, Roger. À beira da falésia: a história entre incertezas e inquietude. Porto Alegre: Ed.UFRGS, 2002. A mão do autor e a mente do editor. São Paulo: Ed.Unesp, 2014.

COPPES JR., Gerson Ribeiro. Forjando o historiador: periodização e longa Idade Média. Faces da História, Assis, v. 2, n. 2, p. 202-206, jun./dez., 2015.

ELIAS, Norbert. Introdução à sociologia. Lisboa: Edições 70, 2008.

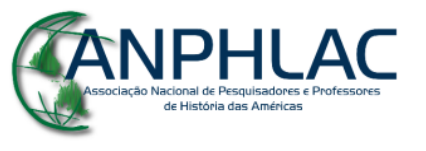

Revista Eletrônica da ANPHLAC, ISSN 1679-1061, №.27 , p. 347-378, Ago./Dez., 2019. http://revista.anphlac.org.br 
FAUSTO, Boris (org.). História Geral da Civilização Brasileira (t. III). Estrutura de poder e economia, 1889-1930 (v. 1). São Paulo: Difel, 1975.

(org.). História Geral da Civilização Brasileira (t. III). Sociedade e instituições, 18891930 (v. 2). São Paulo: Difel, 1977.

(org.). História Geral da Civilização Brasileira (t. III). Sociedade e política, 1930-1964 (v. 3). São Paulo: Difel, 1981.

(org.). História Geral da Civilização Brasileira (t. III). Economia e cultura, 1930-1964 (v. 4). São Paulo: Difel, 1984.

FURTADO, André. As edições do cânone. Da fase buarqueana na coleção História Geral da Civilização Brasileira (1960-1972). Niterói: Eduff, 2016.

Das fortunas críticas e apropriações ou Sérgio Buarque de Holanda, historiador desterrado. Tese (Doutorado em História). Universidade Federal Fluminense - UFF, Niterói, 2018.

GENETTE, Gérard. Paratextos editoriais. São Paulo: Ateliê Editorial, 2009.

GODECHOT, Jacques. La grande nation: l'expansion revolutionnaire de la France dans le monde, 1789-1799. Paris: Aubier, 1956.

LE GOFF, Jacques. Para um novo conceito de Idade Média: tempo, trabalho e cultura no Ocidente. Lisboa: Editorial Estampa, 1979.

Un long Moyen Âge. Paris: Tallandier, 2004.

LÉVY-BRUHL, Lucien. Les fonctions mentales dans les sociétés inférieures. Paris: PUF, 1910. La mentalité primitive. Paris: Alcan, 1922.

MARTÍNEZ, Teodoro Hampe. Ruggiero Romano (1923-2002), gran maestro de la historia económica. Historica, Lima, v. 25, n. 2, p. 225-234, 2001

MASSI, Fernanda. Franceses e norte-americanos nas ciências sociais brasileiras, 1930-1960. In: MICELI, Sérgio (org.). História das Ciências Sociais no Brasil (v. 1). São Paulo: Vértice / Finep / Idesp, 1989.

MERINO, Luis. Don Eugenio Pereira Salas (1904-1979), fundador de la historiografia musical en Chile. Revista Musical Chilena, Santiago, v. XXXIII, n. 148, p. 66-87, 1979.

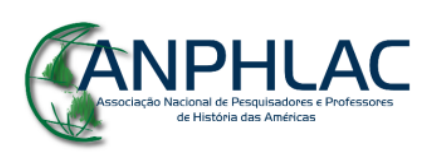

Revista Eletrônica da ANPHLAC, ISSN 1679-1061, №.27 , p. 347-378, Ago./Dez., 2019. http://revista.anphlac.org.br 
MICELI, Sérgio (org.). História das Ciências Sociais no Brasil (v. 1). São Paulo: Vértice / Finep / Idesp, 1989.

MOTTA, Rodrigo Patto Sá. As universidades e o regime militar: cultura política brasileira e modernização autoritária. Rio de Janeiro: Zahar, 2014.

PALMER, Robert Roswell. The age of democratic revolution: a political History of Europe and America, 1760-1800. New Jersey: Princeton University Press, 1959.

REVEL, Jacques. Mentalidades. In: BURGUIÈRE, André (org.). Dicionário das ciências históricas. Rio de Janeiro: Imago, 1993.

RINGUELET, Silvia Pérez. Entrevista al profesor Ruggiero Romano. Boletín de História Social Europea, La Plata, n. 3, p. 69-79, 1991.

RODRIGUES, Lidiane Soares. A produção social do marxismo universitário. Mestres, discípulos e "Um seminário" em São Paulo (1958-1978). Tese (Doutorado em História). Universidade de São Paulo - USP, São Paulo, 2012.

ROLLEMBERG, Denise; QUADRAT, Samanta Viz (orgs.). A construção social dos regimes autoritários. Brasil e América Latina (v. 2). Rio de Janeiro: Civilização Brasileira, 2010.

SILVA, Bruno. Genealogias mazombas: castas luso-brasileiras em crônicas coloniais. Niterói: Eduff, 2016.

SILVA, Renán. Lugar de dúvidas: sobre a prática da análise histórica, breviário de inseguranças. Belo Horizonte: Autêntica, 2015.

"La conexión chilena": el avance y la modernización de los estúdios históricos en América Latina en los años 1960 (prelo).

SORÁ, Gustavo. Misión de la edición para una cultura en crisis. El Fondo de Cultura Económica y el americanismo en Tierra Firme. In: ALTAMIRANO, Carlos (dir.). Historia de los intelectuales en América Latina: los avatares de la "ciudad letrada" en el siglo XX (vol II). Buenos Aires: Katz, 2010.

VENANCIO, Giselle Martins. Presentes de papel: cultura escrita e sociabilidade na correspondência de Oliveira Vianna. Estudos Históricos, Rio de Janeiro, v. 2, n. 28, p. 23-47, jul./dez. 2001.

VENANCIO, Giselle Martins; FURTADO, André. Passados (im)perfeitos ou a ótica buarqueana sobre o Império do Brasil na América. Revista Brasileira de História, São Paulo, v. 36, n. 73, jul./dez. 2016.

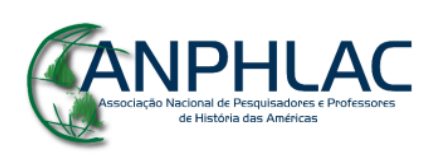

Revista Eletrônica da ANPHLAC, ISSN 1679-1061, №.27 , p. 347-378, Ago./Dez., 2019. http://revista.anphlac.org.br 
VERLINDEN, Charles. Les origines coloniales de la civilisation atlantique. Cahiers d'Histoire Mondiale - Journal of world history - Cuardenos de história mundial, UNESCO, Paris, v. 1, 1953, p. 378-398.

Précédents médiévaux de la colonie en Amérique. Periode coloniale. Ciudad de México: Instituto Panamericano de Geografía e Historia, Comisión de Historia, 1954.

Les origines coloniales de la civilisation atlantique. De la Renaissance à l'âge des lumières. Paris: Albin Michel, 1966.

\section{GANPHLAC}

Revista Eletrônica da ANPHLAC, ISSN 1679-1061, №.27 , p. 347-378, Ago./Dez., 2019. http://revista.anphlac.org.br 